\title{
In Vitro and In Vivo Models for the Study of Human Polyomavirus Infection
}

\author{
Heidi Barth ${ }^{1,2}, *$, Morgane Solis ${ }^{1,2}$, Wallys Kack-Kack ${ }^{1,2}$, Eric Soulier ${ }^{2}$, Aurélie Velay ${ }^{1,2}$ \\ and Samira Fafi-Kremer ${ }^{1,2}$ \\ 1 Laboratoire de Virologie, Hôpitaux Universitaires de Strasbourg, 3 rue Koeberlé, 67000 Strasbourg, France; \\ morgane.solis@chru-strasbourg.fr (M.S.); wallys.kack-kack@chru-strasbourg.fr (W.K.-K.); \\ aurelie.velay@chru-strasbourg.fr (A.V.); samira.fafi-kremer@chru-strasbourg.fr (S.F.-K.) \\ 2 Université de Strasbourg, INSERM, IRM UMR-S 1109, 4 rue Kirschleger, 67000 Strasbourg, France; \\ eric.soulier@unistra.fr \\ * Correspondence: heidi.barth@chru-strasbourg.fr; Tel.: +33-3-69-55-15-48
}

Academic Editor: Alexander Ploss

Received: 4 August 2016; Accepted: 13 October 2016; Published: 22 October 2016

\begin{abstract}
Developments of genome amplification techniques have rapidly expanded the family of human polyomaviruses (PyV). Following infection early in life, PyV persist in their hosts and are generally of no clinical consequence. High-level replication of PyV can occur in patients under immunosuppressive or immunomodulatory therapy and causes severe clinical entities, such as progressive multifocal leukoencephalopathy, polyomavirus-associated nephropathy or Merkel cell carcinoma. The characterization of known and newly-discovered human PyV, their relationship to human health, and the mechanisms underlying pathogenesis remain to be elucidated. Here, we summarize the most widely-used in vitro and in vivo models to study the PyV-host interaction, pathogenesis and anti-viral drug screening. We discuss the strengths and limitations of the different models and the lessons learned.
\end{abstract}

Keywords: polyomavirus; in vitro models; animal models; tropism; entry; pathogenesis

\section{The Growing Family of Human PyV}

Mouse polyomavirus (PyV), discovered in the 1950s, was the founder of the PyV family. It was termed polyoma (meaning "many tumors")-virus because of its ability to produce tumors in mice [1]. In 1971, the first two human PyV were discovered independently in specimens from immunocompromised patients and were named after the patients' initials: BK and JC. BK polyomavirus (BKPyV) was isolated from the urine of a kidney transplant recipient [2], and JC polyomavirus (JCPyV) was identified in the brain tissue of a patient with a history of Hodgkin's lymphoma and progressive multifocal leukoencephalopathy [3]. However, over 35 years passed before advances in high-throughput sequencing technologies were to suddenly increase the discovery of new human PyV (Table 1). In 2007, Karolinska Institute (KI) PyV [4] and Washington University (WU) $\mathrm{PyV}$ [5] were discovered by means of the random polymerase chain reaction (PCR) amplification and high-throughput deoxyribonucleic acid (DNA) sequencing strategy involving respiratory samples from patients with acute respiratory tract infections. In 2008, Merkel cell PyV (MCPyV) was discovered by analyzing complementary DNA (cDNA) sequences prepared from Merkel cell carcinoma specimens using pyrosequencing technology followed by the subtraction of human reads so as to identify novel viral sequences [6]. 
Table 1. Discovery of human polyomaviruses and associated diseases.

\begin{tabular}{|c|c|c|c|c|c|c|c|}
\hline Human Polyomavirus & Abbreviation & Year of Discovery & $\begin{array}{l}\text { NCBI RefSeq or } \\
\text { GenBank Accession }\end{array}$ & Source of Isolation & Seroprevalence $(\%) *$ & Associated Disease & Ref. \\
\hline BK polyomavirus & BKPyV & 1971 & NC_001538 & Urine & $80-90^{\text {(a) }}$ & Nephropathy, hemorrhagic cystitis & [2] \\
\hline JC polyomavirus & $\mathrm{JCPyV}$ & 1971 & NC_001699 & Brain & $40-55^{\text {(b) }}$ & $\begin{array}{l}\text { Progressive multifocal } \\
\text { leukoencephalopathy }\end{array}$ & [3] \\
\hline Karolinska Institute polyomavirus & KIPyV & 2007 & NC_009238 & Respiratory tract & $55-90$ & Not known & {$[4]$} \\
\hline Washington University polyomavirus & WUPyV & 2007 & NC_009539 & Respiratory tract & $70-90$ & Not known & [5] \\
\hline Merkel cell polyomavirus & MCPyV & 2008 & NC_010277 & Skin tumor & $60-80$ & Merkel cell carcinoma & [6] \\
\hline Human polyomavirus 6 & HPyV6 & 2010 & NC_014406 & Normal skin & $70-75$ & Not known & [7] \\
\hline Human polyomavirus 7 & HPyV7 & 2010 & NC_014407 & Normal skin & $35-62$ & Pruritic rash & [7] \\
\hline $\begin{array}{l}\text { Trichodysplasia spinulosa-associated } \\
\text { polyomavirus }\end{array}$ & TSPyV & 2010 & NC_014361 & Skin lesion & $70-84$ & Trichodysplasia spinulosa & [8] \\
\hline Human polyomavirus 9 & HPyV9 & 2011 & NC_015150 & Blood and urine & $18-50$ & Not known & [9] \\
\hline Malawi polyomavirus & MWPyV & 2012 & NC_018102 & Stool & $42-75$ & Not known & [10] \\
\hline Human polyomavirus 10 & HPyV10 & 2012 & JX262162 & Condyloma & 99 & Not known & [11] \\
\hline Mexico polyomavirus & MXPyV & 2012 & JX259273 & Stool & Not known & Not known & [12] \\
\hline St Louis polyomavirus & STLPyV & 2012 & NC_020106 & Stool & 70 & Not known & [13] \\
\hline Human polyomavirus 12 & HPyV12 & 2013 & NC_020890 & Liver & 23 & Not known & [14] \\
\hline New Jersey polyomavirus & NJPyV & 2013 & NC_024118 & Muscle biopsy & Not known & Not known & [15] \\
\hline
\end{tabular}

* References: [14,16-21] ${ }^{(\mathrm{a})}$ Following analysis based on the entire genome or sequence of the major viral capsid protein VP1, BKPyV strains have been classified into four different genotypes (I-IV), corresponding to four serologically-different subtypes. Genotype I is the most prevalent worldwide, while Genotype IV is found solely in East Asia and Europe. In contrast, Genotypes II and III are rarely detected in the human population [22]. (b) Only one serotype has to date been reported for JCPyV, despite the existence of seven genotypes, numbered 1-8, with Type 5 reclassified as a member of Type 3, and numerous subtypes [23]. European populations typically harbor Types 1 and 4 , although Type 2 subtypes have also been described [24,25]. African populations are often associated with Types 3 and 6, with the former also found in Middle-Eastern populations [26], while numerous subtypes from Types $2(2 \mathrm{~A}, 2 \mathrm{~B}, 2 \mathrm{D}$ and $2 \mathrm{E})$ and $7-8(7 \mathrm{C}, 8 \mathrm{~A}$ and $8 \mathrm{~B})$ are found in Asia and Oceania [27,28]. Coevolution of JCPyV with human populations is thought to have given rise to the different genotypes and could account for their association with specific ethnic groups [29]. 
Rolling circle amplification (RCA) techniques identified human polyomavirus 6 (HPyV6) and HPyV7 from skin samples [7], and trichodysplasia spinulosa-associated PyV (TSPyV, also called HPyV8) in skin lesions from patient with trichodysplasia spinulosa [8]. In 2011, a generic PyV PCR assay using primers that have been designed to target conserved regions of the gene encoding the major capsid protein of PyV led to the discovery of HPyV9 in a kidney transplant patient [9]. Only one year later, Malawi PyV (MWPyV) was identified from stool specimens of a one-year-old healthy Malawi child using RCA and pyrosequencing [10]. In the same year, the complete sequenced genome of HPyV10 was detected in condyloma specimens from a patient with a rare genetic disorder known as warts, hypogammaglobulinemia, infections and myelokathexis syndrome (WHIM) [11]. In addition to these cases, the isolation of a PyV from stool samples of a Mexican child presenting with diarrhea has also been described (Mexico PyV; MXPyV) [12]. An analysis of the nucleotide sequences of MWPyV, HPyV10 and MXPyV isolates revealed 95\%-99\% homology, suggesting that these PyV are closely-related variants. In 2013, Saint Louis PyV (STLPyV) was identified in the stool sample of a healthy child [13], with nucleotide sequence analysis demonstrating that STLPyV is most closely related to MWPyV [13]. Generic PyV PCR targeting the major viral capsid protein also identified a novel PyV in human liver tissue, called HPyV12 [14]. Phylogenetic analyses of HPyV12 did not reveal a close relationship with known human PyV, indicating that HPyV12 belongs to a different PyV species. The last novel PyV was identified in a muscle biopsy of a pancreatic transplant recipient suffering from retinal blindness and vasculitic myopathy, using high-throughput sequencing, which was named New Jersey PyV (NJPyV). This variant appears to exhibit a tropism for vascular endothelial cells [15].

\section{The PyV Life Cycle}

Human PyV are small non-enveloped viruses. The genome of PyV consists of an $\sim 5 \mathrm{~kb}$-long circular double-stranded DNA and is encapsidated in an icosahedral shell composed of 72 pentamers of the capsid protein VP1. VP1 determines antigenicity and receptor specificity and has thus a significant impact on the attachment, tissue tropism and pathogenicity of PyV. In addition to the major capsid protein VP1, two minor capsid proteins, VP2 and VP3, occupying the interior of the capsid, have been described [16] (Figure 1). Interestingly, MCPyV lacks the VP3 minor capsid protein, and phylogenetic analyses indicate that $\mathrm{MCPyV}$ is a member of a divergent clade of polyomaviruses that lack the conserved VP3 N-terminal motif [30]. The genome of all PyV contains an $~ 500$-bp non-coding sequence referred to as the non-coding control region (NCCR), which harbors the origin of DNA replication, as well as transcription promoters and regulatory elements. The NCCR region separates the PyV genome into the early region encoding the tumor antigens (TAgs), which are synthesized before viral DNA replication, and the late region encoding the viral capsid proteins VP1, VP2 and VP3 (Figure 1). TAgs are expressed from a variably-spliced viral transcript resulting in different forms of TAgs (large (LTAg), middle (MTAg) and small (sTAg) forms). Unlike the other human PyV, BKPyV and JCPyV encode an accessory protein in the late region, referred to as the agnoprotein [16]. In addition, viral encoded miRNAs, which have the ability to negatively regulate the expression of viral gene expression, have been found to be encoded by BKPyV, JCPyV and MCPyV [31-34].

PyV entry is initiated by the major capsid protein VP1, which attaches to cellular receptors to promote internalization. Sialylated glycans have been identified as functional receptors for several human PyV. Sialic acids are abundantly expressed on $\mathrm{N}$ - or $\mathrm{O}$-linked glycoproteins and gangliosides. BKPyV uses the common $\alpha 2,8$-disalic acid motif on b-series gangliosides to infect cells [35,36]. Although JCPyV binds to multiple sialic acid-containing gangliosides, the linear $\alpha 2,6$-linked lacto-series tetrasaccharide $\mathrm{c}$ (LSTc) has been established as a functional receptor for JCPyV [37,38]. In addition to LSTc, other studies have also evidenced the importance of other cellular components for JCPyV entry, such as the serotonin receptor 5HT2A $[39,40]$. Interestingly, TSPyV can interact with terminal sialic acids in $\alpha 2,3-, \alpha 2,6-$ and $\alpha 2,8$-linkages, and a sialylated glycolipid has been proposed to initiate viral entry [41]. Glycan microarray analysis revealed that HPyV9 VP1 also interacts with sialic acids with an unexpected preferential binding to $\alpha-5-N$-glycolylneuraminic acid (Neu5Ac), which humans 
can acquire only from diet sources that are rich in Neu5Ac, such as red meat and milk products [42]. Unlike other PyV, MCPyV uses sulfated carbohydrates termed glycosaminoglycans as attachment receptors and sialylated glycans as secondary, post-attachment co-receptors during viral entry [43,44]. To date, the cell surface receptors for KIPyV, WUPyV, HPyV6 and HPyV7 are unknown. Single-cell binding studies indicated that sialylated glycans are likely not required for viral attachment of HPyV6 and HPyV7 [45]. Structural analysis of the major capsid protein VP1 revealed that KIPyV and WUPyV VP1 possess unique structural features that suggest engagement of non-sialylated receptor types [46]. Different entry pathways have been described for PyV depending on both cell type and virus. JCPyV virus enters cells via clathrin-mediated endocytosis, while for BKPyV, caveolae-dependent endocytosis and the caveolin- and clathrin-independent entry pathway have been observed [47,48]. However, further studies are warranted to gain a deeper insight into the cellular receptors and entry pathways of known and newly-discovered PyV. Following entry, PyV have to traffic from the cytoplasm to the nucleus, where the uncoated genome is accessible to the replication machinery of the host cell. TAgs are required for viral replication, cellular transformation or tumorigenicity. Virion assembly occurs in the nucleus; however, very little is known about the egress of viral particles. PyV establish a life-long persistence that is probably achieved by a very low level of viral replication. Interestingly, PyV genomes have been shown to be associated with histone proteins [49,50], suggesting that PyV genomes are susceptible to epigenetic regulation.
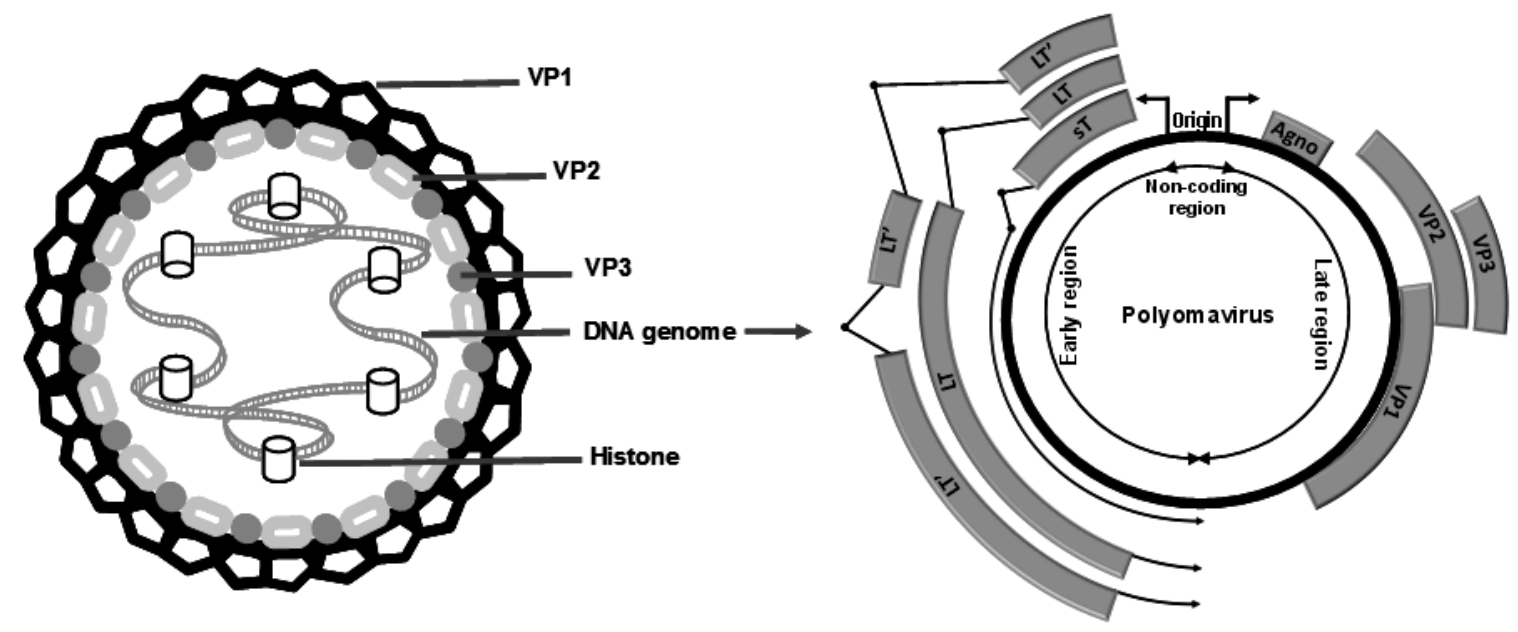

Figure 1. Human PyV particles are composed of 72 pentamers of the capsid protein VP1, with one of the minor capsid proteins VP2 or VP3 in the center of each pentamer. The human PyV genome is divided into three regions: a non-coding region, containing the early and late promoters, transcription sites and the origin of replication; an early region encoding small $\mathrm{T}$ antigens (sT), large T antigens (LT) and alternatively-spliced LT antigens ( $\left.\mathrm{LT}^{\prime}\right)$; and a late region encoding the viral structural proteins VP1, VP2 and VP3. Among human polyomaviruses, only BKPyV and JCPyV encode an agnoprotein (agno) upstream of VP1. Merkel cell PyV (MCPyV) does not encode the minor capsid protein VP3.

\section{PyV-Associated Pathologies}

PyV are ubiquitous, clinically-silent human pathogens indicating that PyV and their hosts establish a symbiotic relationship, although it remains unclear to what extent these two partners benefit. A respiratory route of transmission of PyV has been hypothesized [51]. However, PyV have also been detected in different water environments, including swimming pool waters [52,53], implying that PyV are disseminated through fecal or urine contamination of water. Primary infection is usually asymptomatic and occurs in childhood or during adolescence. A recently-conducted seroepidemiology study of 10 human polyomaviruses in the U.S. population demonstrated that all participants were seropositive for at least one $\mathrm{PyV}$, with a mean of 7.3 PyV and with seroprevalences ranging from 17.6\% (for HPyV9) to 99.1\% (for HPyV10) [20]. PyV establish a silent, persistent infection in various organs 
and tissues, such as the urogenital tract, kidneys, the bone marrow, the skin and the brain. Diseases associated with PyV have been so far exclusively described in immunocompromised individuals or patients with immunological abnormalities. Current evidence indicates that PyV-specific T cells and also neutralizing antibodies play a crucial role in the control of PyV replication and recovery from PyV-associated diseases. Specific direct antiviral molecules against PyV are lacking. Thus, patient survival is mainly dependent on the reconstitution of PyV-specific T-cell response. For more detailed reviews on these topics, the reader is referred to other studies [54-57]. At present, five members of the human PyV family have been associated with specific pathologies (Table 1):

$\mathrm{BKPyV}$ is the causative agent of BKPyV-associated nephropathy in kidney transplant recipients and hemorrhagic cystitis in bone marrow transplant patients. Primary sites for BKPyV replication are the renal and uro-epithelium, resulting in lytic destruction of these cells. Replication of BKPyV has been observed under all combinations of immunosuppression [55].

JCPyV causes progressive multifocal leukoencephalopathy (PML), a rapidly-progressive and fatal demyelinating disease. JCPyV replicates in oligodendrocytes and to a lesser extent in astrocytes, leading to demyelinated lesions accompanied by progressive accumulation of neurological deficits and ultimately death. JCPyV causes PML in immunocompromised patients, such as patients with HIV / AIDS, hematological malignancies and in patients receiving immunomodulatory medication, such as integrin very late antigen-4 (VLA-4) monoclonal antibody (natalizumab, Tysabri ${ }^{\circledR}$ ), leukocyte function associated antigen 1 (LFA-1) monoclonal antibody (efalizumab, Raptiva ${ }^{\circledR}$ ) and CD20 monoclonal antibody (rituximab, MabTher ${ }^{\circledR}$ ) for the treatment of multiple sclerosis, Crohn's disease, lymphoma, severe forms of plaque-type psoriasis and rheumatic diseases [58]. In addition to PML, $\mathrm{JCPyV}$ can cause other neurological disorders, such as JCPyV granule cell neuronopathy, JCPyV encephalopathy and meningitis [59].

TSPyV causes the rare skin disease trichodysplasia spinulosa (TS) affecting solid-organ transplant patients undergoing immunosuppressive therapy, especially kidney (and kidney-pancreas) and heart transplant recipients, as well as lymphocytic leukemia patients. The disease is characterized by the development of follicular papules and keratin spines (spicules), predominantly in the face, often accompanied by alopecia of the eyebrows and eyelashes. Histologically, TS is characterized by an abnormal maturation and marked distention of the hair follicles. The inner root sheath cells are highly proliferative and contain excessive amounts of trichohyalin and intraepithelial viral inclusions [60,61].

$\mathrm{MCPyV}$ was discovered as the causative agent of Merkel cell carcinoma (MCC), an aggressive neuroendocrine skin cancer with high rates of recurrence, metastatic spread and mortality. Primary risk factors for MCC development include immunosuppression, ultraviolet (UV) light exposure and advanced age [62]. Among the 13 human PyV, MCPyV is the only one that has been clearly associated with cancer in humans. MCPyV DNA is found clonally integrated in the tumor genome of MCC with persistent expression of LTAg and sTAg. LTAg isolated from tumors typically contains a truncated form of LTAg that is functionally incapable of supporting viral replication. Although MCPyV is often present on healthy human skin, efforts to determine the natural host cell type that supports MCPyV infection have only very recently succeeded. Liu and colleagues demonstrated that dermal fibroblasts in human skin support the full MCPyV life cycle [63].

Most recently, HPyV7 was associated with pruritic rash and viremia in lung transplant recipients on immunosuppressive therapy [64]. Rennspiess and colleagues reported the detection of HPyV7 DNA and LTAg expression in human thymic epithelial tumors [65]. Although further studies are necessary to investigate these associations, it is not unlikely that HPyV7, as well as other recently-discovered PyV might be associated with novel pathogenicity in immunocompromised individuals.

\section{Experimental Model Systems to Study PyV Infection}

In vitro and in vivo models are instrumental for the understanding of the viral life cycle, the pathogenicity and the identification of compounds with antiviral activity. Recombinant proteins, virus-like particles, virus pseudoparticles and cell culture-derived infectious viruses are most widely 
used to recapitulate the viral life cycle, to evaluate the prevalence of virus-specific antibodies and to identify inhibitors that target all aspects of the viral life cycle. In contrast, animal models are important tools for investigating the pathological mechanisms underlying virus-associated diseases and for preclinical testing of antiviral drugs or vaccines.

\subsection{VP1 Pentamers, PyV-Like Particles and PyV Pseudoparticles}

Pentamers of the PyV capsid protein VP1, obtained from bacterial expression vectors encoding for VP1, represent the smallest in vitro model. For example, VP1 pentameric subunits have been used successfully to recapitulate early events in JCPyV and TSPyV infection, including receptor specificity, intracellular trafficking routes of $\mathrm{PyV}$, as well as structural studies of VP1-receptor complexes $[37,41,66]$. Since the insights gained with VP1 pentamers were in line with the findings obtained with infectious PyV, VP1 pentameric subunits represent an important tool for recently-discovered PyV that are difficult to propagate in cell culture.

PyV-like particles (PyVLP) and PyV pseudoparticles (PsV) consist of stable self-assembled capsid proteins without viral DNA. Yeast and baculovirus expression systems have been used to efficiently produce PyVLP [67]. In these systems, the expression of the major capsid protein VP1 results in self-assembled VP1-derived PyVLP [68-71]. Microplate enzyme immunoassay coated with PyVLP allowed studies on PyV seroprevalence rates [72-75]. At present, JCPyVLP are used in a second-generation enzyme-linked immunosorbent assay (ELISA) to detect anti-JCPyV antibodies in human serum [76]. This assay is in clinical use as a risk stratification tool for PML in patients with natalizumab treatment $[76,77]$. Similarly, a MCPyVLP-based immunoassay has been developed to detect anti-VP1 MCPyV antibodies and to evaluate their prognostic value in patients with MCC [78].

$\mathrm{PsV}$ are produced by transfecting human cell lines with expression vectors that encode PyV capsid proteins. Production of $\mathrm{BKPsV}, \mathrm{JCPsV}, \mathrm{MCPsV}$ and $\mathrm{TSPsV}$ has been reported using the embryonic kidney-derived cell line 293TT [41,44,79]. Co-transfection with vectors that encode a reporter protein, such as green fluorescent protein (GFP) or Gaussia luciferase, enables rapid quantification of PsV entry into target cells. PsV have turned out to be a valuable tool for the analysis of the early steps of the PyV life cycle, such as viral attachment and entry. Using MCPsV, Schowalter and colleagues [44] demonstrated that MCPyV uses glycosaminoglycans as initial attachment receptors followed by an interaction with sialylated host cell factors. In an effort to gain a deeper insight into the cellular tropism of PyV, 60 human tumor cell lines were transduced with MCPsV and BKPsV, respectively. MCPsV and BKPsV efficiently transduced many of the same cell types, but also many distinct cell types; however, no clear preference for a tissue type emerged [80]. Though PsV are instrumental in deciphering virus interactions with cell surface receptors, they cannot be used to identify the cellular factors required for virus replication and assembly in the host cells. Recently, JCPsV have been used to study the possible inhibitory effects of chemical compounds mimicking cell surfaces molecules involved in JCPyV binding, such as sialic acids or lacto-series tetrasaccharide $[81,82]$. Interestingly, several molecules with inhibitory activity have been identified and may pave the way for the development of novel anti-JCPyV therapeutic strategies. On the other hand, BKPsV representing different genotypes have been generated to study the activity of neutralizing antibodies from sera of healthy human subjects, kidney transplant recipients and commercially available human immune globulin preparations designed for intravenous immunoglobulin (IVIG) therapy [83-85]. Results of these high-throughput serological neutralization studies demonstrated that BKPyV genotypes are distinct serotypes, suggesting that the absence of neutralizing antibodies against a different BKPyV genotype may favor BKPyV replication in the transplant recipient [83,84]. Analysis of neutralizing antibodies present in immunoglobulin preparations showed that they were able to neutralize all BKPyV genotypes [85]. Prospective cohort studies are now warranted to evaluate the potential protective role of BKPyV neutralizing antibodies in BKPyV-associated diseases. Finally, PsV-based neutralization assays have been used to assess the induction of the antibody responses of potential PyV vaccine candidates. Recently, a PML patient has been vaccinated with JCPyVLP, and the induced humoral 
immune response was assessed by JCPsV-based neutralization assays. After the vaccination, high neutralizing antibody titers against wildtype and mutant JCPyV were observed, and the increase of the neutralizing antibody response was associated with an arrest of PML lesion progression [86].

\subsection{Cell Culture-Derived Infectious PyV}

Attempts to efficiently propagate $\mathrm{PyV}$ in cell culture have so far succeeded for BKPyV, JCPyV and MCPyV. For BKPyV and JCPyV, different genetic types have been described, the so-called archetype and rearranged variant. Transient shedding of $\mathrm{BKPyV}$ or JCPyV in the urine of healthy individuals demonstrates the presence of the archetype, in which the NCCR is a highly conserved DNA sequence block. It is thought that the archetype is contracted in childhood and then establishes persistent infection in the host. High-level replication of BKPyV and JCPyV has been observed in immunocompromised individuals and is associated with the emergence of the rearranged variant. Rearranged variants of $\mathrm{BKPyV}$ and JCPyV are characterized by duplications and deletions of DNA sequence blocks in the NCCR, which enhances viral replication and assembly, leading to enhanced cytopathology. Archetype and rearranged variants of BKPyV and JCPyV can be efficiently propagated in the 293TT human embryonic kidney cell line [87]. Following transfection of episomal PyV DNA into 293TT cells, viral replication, expression of capsid proteins and production of infectious progeny have been demonstrated. Why do 293TT cells support efficient propagation of BKPyV and JCPyV? 293TT cells carry an integrated copy of the simian PyV SV40 genome and a plasmid encoding the cDNA of the simian PyV SV40 LTAg [88]. Constitutive expression of simian PyV SV40 LTAg in these cells drives efficient BKPyV and JCPyV DNA replication from their origins of replication. Interestingly, 293TT cells failed to support replication of other PyV, such as MCPyV, KIPyV and WUPyV. The absence of significant replication of these viruses in 293TT cells can be probably explained by the fact that the simian PyV SV40 LTAg coding sequence has a higher similarity to the LTAg of BKPyV and JCPyV than to the LTAg of MCPyV, KIPyV and WUPyV [87]. Indeed, efficient propagation of MCPyV has been reported in 293TT cells co-transfected with plasmids carrying LTAg and sTAg from MCPyV, named 293-4T cells [44]. The observation that MCPyV-specific TAg expression is a limiting factor in MCPyV propagation may help to develop PyV-permissive cell-culture systems for other, yet unculturable PyV.

Although 293TT cells provide a convenient cell culture system for large-scale propagation of PyV, these transformed cells do not represent a suitable model for the study of the viral life cycle in the natural host cell type. For example, in patients with BKPyV-associated diseases, bladder and renal tubular epithelial cells are the major sites of BKPyV replication. Thus, human renal proximal tubule epithelial cells (RPTEC) are currently used as the state-of-the-art model to study BKPyV infection in vitro [89]. However, RPTEC enter into replicative senescence, which restricts their proliferative potential and the experimental design. Recently, Justice and colleagues [90] assessed host nuclear proteomic changes in BKPyV-infected RPTEC and demonstrated that the host cell DNA damage response signaling and DNA repair pathways were among the most affected host proteins. This study confirmed the results of previous studies with RPTEC indicating that BKPyV usurps proteins implicated in cell-cycle control, DNA replication and repair for efficient viral gene expression and replication [91,92]. This is not surprising because PyV must overcome their limited genome coding capacity and, therefore, rely heavily on the host cellular machinery to replicate their genome. Interestingly, rearranged BKPyV has been shown to replicate in a wide range of different cell types, such as human ovarian, brain and melanoma cancer cell lines, monkey kidney cell lines, i.e., Vero and CV-1 [80,93], human salivary gland cells $[93,94]$ and human fetal lung fibroblast (MRC-5) cells (Barth $\mathrm{H}$. and Soulier E. unpublished observation). A link between BKPyV and the respiratory tract is of particular interest since respiratory transmission routes have been proposed for PyV [51].

In vivo, JCPyV has a major tropism for glial cells and infects productively mainly oligodendrocytes and, to a lesser extent, astrocytes. Various differentiation protocols have been developed to obtain oligodendrocytes and their progenitors from human embryonic stem cells (hESC) [95]. hESC-derived oligodendrocytes are susceptible to cell-culture derived JCPyV [96]. However, the differentiation of 
oligodendrocytes from hESC remains a challenge, and therefore, the human fetal glial cell line SVG, which constitutively expresses simian PyV SV 40 LTAg, has been mostly used to study JCPyV infection. The SVG cell line was established in 1985 [97] and has been provided by the American Type Culture Collection (ATCC) since 1987. In 2014, Henriksen and colleagues [98] reported that a subpopulation of SVG p12 cells provided by ATCC is productively infected with BKPyV and that BKPyV was present in SVG p12 cells at least since 2006. Since BKPyV and JCPyV are closely related and share up to $70 \%$ nucleotide sequence identity, the results obtained in these cells should be taken with caution because the presence of BKPyV may have influenced the results on JCPyV infection. The SVG-A cell line, another subclone of the original SVG human glial cell line, did not contain BKPyV and can be used as an alternative SVG cell line [98]. JCPyV archetype and rearranged variants replicate also efficiently in COS-7 cells (CV-1 cells transformed by an origin-defective mutant of simian PyV SV40 which encodes wildtype $\mathrm{T}$ antigen).

Cell culture-derived infectious BKPyV and JCPyV and their physiologically-relevant primary cell culture models are most widely used to study the interplay between PyV and the host cell. Application of these models in routine drug screening processes is limited due to the lack of fluorescent-labelled recombinant PyV. Current antiviral screens with cell culture-derived infectious PyV consist of quantification of PyV genomes in cells by real-time quantitative PCR (qPCR) or the detection of PyV capsid proteins by immunofluorescence staining, which are time consuming and labor intensive. Using the immunofluorescence approach, Brickelmaier and colleagues [99] screened 2000 approved drugs for their anti-JCPyV activity in SVG-A cells and identified 14 potential drug candidates. However, the production of recombinant PyV strains carrying a reporter gene that remains replication-competent and produces viral progeny might facilitate anti-viral drug screening. Recently, Dang and colleagues [100] developed a JCPyV construct containing the iLOV gene, a 336-bp improved light, oxygen or voltage-sensing domain of the plant phototropin gene. Insertion of the iLOV gene into the JCPyV genome allowed full viral replication and production of viral particles in 293FT human embryonic kidney cells. The utility of JCPyV-iLOV has now to be validated in physiologically-relevant primary cell culture models.

\subsection{Animal Models}

The development of animal models to study PyV infection is hampered by the narrow host range and cell specificity of these viruses. For example, inoculation of JCPyV into mice or hamsters resulted in tumor formation, but did not recapitulate the demyelinating disease caused by JCPyV in humans [101]. Currently-available small animal models for PyV infection include transgenic models, xenografts, humanized mice and infectious mouse PyV models.

\subsubsection{Transgenic Mouse Model}

Several transgenic mice harboring the early region of PyV have been used to study the role of TAgs in the pathogenesis of PyV-associated diseases. Transgenic mice expressing JCPyV TAgs in all cells exhibited a shaking disorder and dysmyelination in the central nervous system, but not the peripheral nervous system [102]. Furthermore, expression of TAgs in oligodendrocytes arrested the maturation of oligodendrocytes and the production of myelin $[103,104]$. However, other phenotypes of JCPyV TAg transgenic mice have also been reported, such as adrenal neuroblastomas and malignant peripheral nerve sheath tumors $[105,106]$, suggesting that the genetic background of the mice and the choice of the promoter that drives the expression of the transgene influence the disease phenotype. Similarly, transgenic mice containing the early region of BKPyV developed primary hepatocellular carcinomas and renal tumors [105], but did not recapitulate key characteristics of BKPyV-associated nephropathy. Spurgeon and colleagues [107] therefore used an inducible transgenic mouse model and a keratin 14 promoter, which allows for skin-specific expression of truncated LTAg and wild-type sTAg. Expression of MCPyV TAgs in stratified squamous epithelial cells and Merkel cells of the skin epidermis led to the development of benign epithelial tumors, but not MCC. Inducible expression 
of MCPyV sTAg under the control of a keratin 5 promoter led to squamous cell carcinoma-like lesions [108], indicating that sTAg has the capability for epithelial transformation independent of LTAg. However, lesions resembling MCC either morphologically or biochemically by staining with MCC markers were not detected. Similarly, Shuda and colleagues [109] demonstrated in their transgenic mouse model that sTAg expression induces cell proliferation, but was insufficient to recapitulate MCC. Although these robust transgenic mouse models allow insights into the oncogenic potential of TAgs and their potential cellular interaction partners, they have failed to phenotypically recapitulate the human PyV-associated diseases.

\subsubsection{Xenograft Mouse Model}

Conventional xenograft mouse models consist of the transplantation of cultured human cells in immunocompromised host mice [110]. Transplanted MCPyV-positive MCC cell lines into immunodeficient mice formed tumors, which stained positive for LTAg and cytokeratin-20 (CK20), a marker commonly used in the diagnosis of MCC [111]. Although human xenograft models have limited applications in the study of the mechanisms of PyV pathogenesis, they can be used as predictive preclinical models for new anticancer agents. For example, YM155, a small-molecule inhibitor of survivin, has been tested in MCPyV-positive MCC xenografts. YM155 was non-toxic and led to growth arrest of MCC tumors in these mice [111,112].

\subsubsection{Humanized Mouse Models}

Mice bearing human tissues, including functional human immune systems, are valuable tools to study the pathogenesis of human-specific infectious pathogens. Tan and colleagues [113] engrafted immunodeficient mice with human lymphocytes and thymus to study JCPyV infection. However, mice intraperitoneally inoculated with brain-derived rearranged JCPyV isolate Mad4 or the urine-derived archetype strain did not show signs or symptoms of PML. JCPyV DNA was occasionally detected in blood and urine, and only in a subgroup of mice, anti-JCPyV humoral and cellular immune responses were induced at low levels [113]. The lack of a robust JCPyV replication and pathogenesis in these mice is likely due to the absence of human brain tissue, the cellular target for JCPyV replication. Kondo and colleagues [114] therefore generated a mouse model with humanized glia cells by implanting primary human glial progenitor cells into neonatal immunodeficient and myelin-deficient (Rafg2-/- Mbp shi/shi) mice. The transfer of human glial progenitor cells resulted in a differentiation and colonization of the mouse brain with human glial cells, i.e., oligodendrocytes and astrocytes. Intracerebral inoculation of JCPyV isolate Mad-1 led to virus replication of human astrocytes and glial progenitors, along with focal demyelination and gliosis. The oligodendrocytes were only rarely infected, yet exhibited apoptotic death, suggesting that JCPyV kills them by programming them to undergo apoptosis instead of inducing a lytic infection. This is in contrast to PML in humans, where oligodendrocytes are primarily infected and produce progeny virus. Interestingly, the disease pathogenesis was associated with the emergence of virus mutants harboring mutations in the VP1 region, similar to those observed and isolated from PML patients $[115,116]$. This animal model represents a substantial step forward in modelling JCPyV disease; however, it cannot be used to undertand how JCPyV is transported from the periphery to the central nervous system because JCPyV has been injected into the chimeric mouse brain. Further advances in the development of a humanized model harboring dual engraftments, such as primary human glial progenitor cells and hematopoietic stem cells, may answer this question.

\subsubsection{Mouse PyV Infection Model}

Similar to human PyV, mouse PyV establish a silent persistent infection in natural populations of mice. Genetic differences exist between mouse and human PyV, for example the mouse PyV genome encodes a third TAg named MTAg, which is the principal oncogene of mouse PyV [117]. At present, none of the human PyV has been shown to express MTAg, except TSPyV, as demonstrated recently by 
van der Meijden and colleagues [118]. Furthermore, unlike JCPyV and BKPyV, mouse PyV lack the agnoprotein. The observation that PyV-specific CD4+ and CD8+ T cells are induced in mouse PyV infection $[119,120]$ suggested that mouse PyV infection might be a model to study human PyV infection and pathogenesis. In fact, several early studies addressing mouse PyV infection in T cell-deficient mice demonstrated virus-induced demyelination upon productive viral replication in the central nervous system (CNS). However, the use of these mouse models was stopped due to the results of the outcome of mouse PyV infection in nude mice. Nude mice infected intracranially with mouse PyV developed vertebral tumors, which compressed the peripheral nerves and produced paralysis in the absence of demyelination (reviewed in [121]).

Another approach involves mouse PyV infection in mice bearing allogeneic kidneys to mimic BKPyV-associated nephropathy of kidney transplants recipients. In this mouse PyV-renal transplant model, infection with the mouse PyV wildtype strain A2 resulted in a productive replication in the allogeneic kidney graft, severe graft injury and accelerated kidney graft failure [122]. However, results from this mouse model are difficult to extrapolate to kidney transplant recipients since the recipient mice were not immunosuppressed because allogeneic kidneys are not acutely rejected by immunocompetent mice. To address this issue, Albrecht and colleagues performed kidney transplantations in splenectomized and nephrectomized alymphoplasia (aly/aly) mice, which are unable to mount an adaptive immune response [123]. Although persistent high viral loads were observed in aly/aly mice following acute mouse PyV infection, high viral loads were not associated with increased allograft injury or loss of renal grafts suggesting that PyV-associated nephropathy in mice is dependent on an intact adaptive immune response. These findings are in contrast to BKPyV-associated nephropathy, where viral cytopathic changes in tubular or glomerular epithelial cells are central histopathological features. Further studies are necessary to evaluate the utility of mouse PyV-transplant models for the study of BKPyV-associated nephropathy in humans.

\subsubsection{Simian PyV SV40 Monkey Model}

The simian PyV SV40 infects species of Asian macaque monkeys, especially the rhesus macaque (Macaca mulatta). PyV SV40 is closely related to BKPyV and JCPyV, with which it shares approximately $70 \%$ sequence homology. As with human PyV, SV40 establishes asymptomatic persistent infections in rhesus macaques. SV40 infection in immunodeficiency virus (SIV)-immunosuppressed rhesus monkey can cause demyelinating brain lesions, analogous to PML in immunocompromised patients, and meningoencephalitis with productive SV40 infection of neurons, which parallels JCPyV neuronal infection in immunosuppressed humans [124-127]. Thus, rhesus macaques can serve as an important animal model to study JCPyV primary infection and neuropathogenesis.

\section{Conclusions and Future Perspectives}

Available experimental models have so far focused mainly on BKPyV and JCPyV, which allowed important insights into PyV-host cell interaction and recapitulated some pathological features of PyV-associated diseases. However, it seems that we are just looking at the tip of the iceberg. For example, PyV genomes are packaged with histone proteins in infected cells $[49,50]$, suggesting an epigenetic control of $\mathrm{PyV}$ gene expression. Knowledge of the epigenetic regulation of PyV genomes may help to understand how PyV persistence is established and maintained. Currently, only MCPyV seems to be associated with cancer, although BKPyV LTAg expression has been reported in early prostate cancer precursor lesions and renourinary carcinomas [128,129]. Potential etiologic roles for other PyV in cancer has to be investigated in appropriate model systems. The increasing use of immunosuppressive or immunomodulatory therapy will undoubtedly increase PyV-associated diseases, and efficient antiviral treatments are severely lacking. To facilitate screening of anti-viral drugs, available cell culture models have to be improved, including infectious recombinant reporter viruses to easily visualize virus-infected cells. Great efforts are needed to develop humanized mice models for other PyV, such as mice engrafted with functional human kidney tissue and immune 
system, which may allow studies on BKPyV infection and BKPyV-associated nephropathy. Finally, the iceberg under the water seems relatively large when aiming to address the question of the evolution of human PyV and their role as members of the human virome.

Acknowledgments: We thank Véronique Christ for assistance in preparing and formatting the review.

Conflicts of Interest: The authors declare no conflict of interest.

\section{References}

1. Gross, L. A filterable agent, recovered from Ak leukemic extracts, causing salivary gland carcinomas in $\mathrm{C} 3 \mathrm{H}$ mice. Proc Soc Exp Biol Med 1953, 83, 414-421. [CrossRef] [PubMed]

2. Gardner, S.D.; Field, A.M.; Coleman, D.V.; Hulme, B. New human papovavirus (BK) isolated from urine after renal transplantation. Lancet 1971, 297, 1253-1257. [CrossRef]

3. Padgett, B.L.; Walker, D.L.; ZuRhein, G.M.; Eckroade, R.J.; Dessel, B.H. Cultivation of papova-like virus from human brain with progressive multifocal leucoencephalopathy. Lancet 1971, 297, 1257-1260. [CrossRef]

4. Allander, T.; Andreasson, K.; Gupta, S.; Bjerkner, A.; Bogdanovic, G.; Persson, M.A.A.; Dalianis, T.; Ramqvist, T.; Andersson, B. Identification of a third human polyomavirus. J. Virol. 2007, 81, 4130-4136. [CrossRef] [PubMed]

5. Gaynor, A.M.; Nissen, M.D.; Whiley, D.M.; Mackay, I.M.; Lambert, S.B.; Wu, G.; Brennan, D.C.; Storch, G.A.; Sloots, T.P.; Wang, D. Identification of a novel polyomavirus from patients with acute respiratory tract infections. PLoS Pathog. 2007, 3, e64. [CrossRef] [PubMed]

6. Feng, H.; Shuda, M.; Chang, Y.; Moore, P.S. Clonal integration of a polyomavirus in human merkel cell carcinoma. Science 2008, 319, 1096-1100. [CrossRef] [PubMed]

7. Schowalter, R.M.; Pastrana, D.V.; Pumphrey, K.A.; Moyer, A.L.; Buck, C.B. Merkel cell polyomavirus and two novel polyomaviruses are chronically shed from human skin. Cell Host Microbe 2010, 7, 509-515. [CrossRef] [PubMed]

8. Van der Meijden, E.; Janssens, R.W.A.; Lauber, C.; Bouwes Bavinck, J.N.; Gorbalenya, A.E.; Feltkamp, M.C.W. Discovery of a new human polyomavirus associated with trichodysplasia spinulosa in an immunocompromized patient. PLoS Pathog. 2010, 6, e1001024. [CrossRef] [PubMed]

9. Scuda, N.; Hofmann, J.; Calvignac-Spencer, S.; Ruprecht, K.; Liman, P.; Kühn, J.; Hengel, H.; Ehlers, B. A novel human polyomavirus closely related to the African green monkey-derived lymphotropic polyomavirus. J. Virol. 2011, 85, 4586-4590. [CrossRef] [PubMed]

10. Siebrasse, E.A.; Reyes, A.; Lim, E.S.; Zhao, G.; Mkakosya, R.S.; Manary, M.J.; Gordon, J.I.; Wang, D. Identification of MW polyomavirus, a novel polyomavirus in human stool. J. Virol. 2012, 86, 10321-10326. [CrossRef] [PubMed]

11. Buck, C.B.; Phan, G.Q.; Raiji, M.T.; Murphy, P.M.; McDermott, D.H.; McBride, A.A. Complete genome sequence of a tenth human polyomavirus. J. Virol. 2012, 86, 10887. [CrossRef] [PubMed]

12. Yu, G.; Greninger, A.L.; Isa, P.; Phan, T.G.; Martínez, M.A.; de la Luz Sanchez, M.; Contreras, J.F.; Santos-Preciado, J.I.; Parsonnet, J.; Miller, S.; et al. Discovery of a novel polyomavirus in acute diarrheal samples from children. PLoS ONE 2012, 7, e49449. [CrossRef] [PubMed]

13. Lim, E.S.; Reyes, A.; Antonio, M.; Saha, D.; Ikumapayi, U.N.; Adeyemi, M.; Stine, O.C.; Skelton, R.; Brennan, D.C.; Mkakosya, R.S.; et al. Discovery of STL polyomavirus, a polyomavirus of ancestral recombinant origin that encodes a unique $\mathrm{T}$ antigen by alternative splicing. Virology 2013, 436, 295-303. [CrossRef] [PubMed]

14. Korup, S.; Rietscher, J.; Calvignac-Spencer, S.; Trusch, F.; Hofmann, J.; Moens, U.; Sauer, I.; Voigt, S.; Schmuck, R.; Ehlers, B. Identification of a novel human polyomavirus in organs of the gastrointestinal tract. PLoS ONE 2013, 8, e58021. [CrossRef] [PubMed]

15. Mishra, N.; Pereira, M.; Rhodes, R.H.; An, P.; Pipas, J.M.; Jain, K.; Kapoor, A.; Briese, T.; Faust, P.L.; Lipkin, W.I. Identification of a novel polyomavirus in a pancreatic transplant recipient with retinal blindness and vasculitic myopathy. J. Infect. Dis. 2014, 210, 1595-1599. [CrossRef] [PubMed]

16. DeCaprio, J.A.; Garcea, R.L. A cornucopia of human polyomaviruses. Nat. Rev. Microbiol. 2013, 11, 264-276. [CrossRef] [PubMed] 
17. Nicol, J.T.J.; Leblond, V.; Arnold, F.; Guerra, G.; Mazzoni, E.; Tognon, M.; Coursaget, P.; Touzé, A. Seroprevalence of Human Malawi Polyomavirus. J. Clin. Microbiol. 2014, 52, 321-323. [CrossRef] [PubMed]

18. Lim, E.S.; Meinerz, N.M.; Primi, B.; Wang, D.; Garcea, R.L. Common exposure to STL polyomavirus during childhood. Emerg. Infect. Dis. 2014, 20, 1559-1561. [CrossRef] [PubMed]

19. Van der Meijden, E.; Bialasiewicz, S.; Rockett, R.J.; Tozer, S.J.; Sloots, T.P.; Feltkamp, M.C.W. Different serologic behavior of MCPyV, TSPyV, HPyV6, HPyV7 and HPyV9 polyomaviruses found on the skin. PLoS ONE 2013, 8, e81078. [CrossRef] [PubMed]

20. Gossai, A.; Waterboer, T.; Nelson, H.H.; Michel, A.; Willhauck-Fleckenstein, M.; Farzan, S.F.; Hoen, A.G.; Christensen, B.C.; Kelsey, K.T.; Marsit, C.J.; et al. Seroepidemiology of human polyomaviruses in a US population. Am. J. Epidemiol. 2016, 183, 61-69. [CrossRef] [PubMed]

21. Berrios, C.; Jung, J.; Primi, B.; Wang, M.; Pedamallu, C.; Duke, F.; Marcelus, C.; Cheng, J.; Garcea, R.L.; Meyerson, M.; et al. Malawi polyomavirus is a prevalent human virus that interacts with known tumor suppressors. J. Virol. 2015, 89, 857-862. [CrossRef] [PubMed]

22. Cubitt, C. Molecular Genetics of the BK Virus. In Polyomaviruses and Human Diseases; Ahsan, N., Ed.; Springer: New York, NY, USA, 2006; Volume 577, pp. 85-95.

23. Pavesi, A. African origin of polyomavirus JC and implications for prehistoric human migrations. J. Mol. Evol. 2003, 56, 564-572. [CrossRef] [PubMed]

24. Karalic, D.; Lazarevic, I.; Knezevic, A.; Cupic, M.; Jevtovic, D.; Jovanovic, T. Distribution of JC virus genotypes among serbian patients infected with HIV and in healthy donors. J. Med. Virol. 2014, 86, 411-418. [CrossRef] [PubMed]

25. Zanotta, N.; Delbue, S.; Rossi, T.; Pelos, G.; D’Agaro, P.; Monasta, L.; Ferrante, P.; Comar, M. Molecular epidemiology of JCV genotypes in patients and healthy subjects from Northern Italy. J. Med. Virol. 2013, 85, 1286-1292. [CrossRef] [PubMed]

26. Chehadeh, W.; Kurien, S.S.; Nampoory, M.R. Molecular characterization of BK and JC viruses circulating among potential kidney donors in Kuwait. BioMed Res. Int. 2013, 2013, 683464. [CrossRef] [PubMed]

27. Cui, X.; Wang, J.; Deckhut, A.; Joseph, B.; Eberwein, P.; Cubitt, C.; Ryschkewitsch, C.; Agostini, H.; Stoner, G. Chinese strains (Type 7) of JC Virus are afro-asiatic in origin but are phylogenetically distinct from the mongolian and indian strains (Type 2D) and the korean and japanese strains (Type 2A). J. Mol. Evol. 2004, 58, 568-583. [PubMed]

28. Jobes, D.V.; Friedlaender, J.S.; Mgone, C.S.; Agostini, H.T.; Koki, G.; Yanagihara, R.; Ng, T.C.N.; Chima, S.C.; Ryschkewitsch, C.F.; Stoner, G.L. New JC virus (JCV) genotypes from Papua New Guinea and Micronesia (Type 8 and Type 2E) and evolutionary analysis of 32 complete JCV genomes. Arch. Virol. 2001, 146, 2097-2113. [CrossRef]

29. Cubitt, C.; Cui, X.; Agostini, H.; Nerurkar, V.; Scheirich, I.; Yanagihara, R.; Ryschkewitsch, C.; Stoner, G. Predicted amino acid sequences for 100 JCV strains. J. Neurovirol. 2001, 7, 339-344. [PubMed]

30. Schowalter, R.M.; Buck, C.B. The Merkel cell polyomavirus minor capsid protein. PLoS Pathog. 2013, 9, e1003558. [CrossRef] [PubMed]

31. Seo, G.J.; Fink, L.H.L.; O'Hara, B.; Atwood, W.J.; Sullivan, C.S. Evolutionarily conserved function of a viral microRNA. J. Virol. 2008, 82, 9823-9828. [CrossRef] [PubMed]

32. Theiss, J.M.; Gunther, T.; Alawi, M.; Neumann, F.; Tessmer, U.; Fischer, N.; Grundhoff, A. A comprehensive analysis of replicating merkel cell polyomavirus genomes delineates the viral transcription program and suggests a role for mcv-miR-M1 in episomal persistence. PLoS Pathog. 2015, 11, e1004974. [CrossRef] [PubMed]

33. Rocca, A.; Martelli, F.; Delbue, S.; Ferrante, P.; Bartolozzi, D.; Azzi, A.; Giannecchini, S. The JCPYV DNA load inversely correlates with the viral microrna expression in blood and cerebrospinal fluid of patients at risk of PML. J. Clin. Virol. 2015, 70, 1-6. [CrossRef] [PubMed]

34. Pietilä, T.; Nummi, M.; Auvinen, P.; Mannonen, L.; Auvinen, E. Expression of BKV and JCV encoded microRNA in human cerebrospinal fluid, plasma and urine. J. Clin. Virol. 2015, 65, 1-5. [CrossRef] [PubMed]

35. Low, J.A.; Magnuson, B.; Tsai, B.; Imperiale, M.J. Identification of gangliosides GD1b and GT1b as receptors for BK Virus. J. Virol. 2006, 80, 1361-1366. [CrossRef] [PubMed]

36. Neu, U.; Allen, S.A.; Blaum, B.S.; Liu, Y.; Frank, M.; Palma, A.S.; Stroh, L.J.; Feizi, T.; Peters, T.; Atwood, W.J.; et al. A structure-guided mutation in the major capsid protein retargets BK polyomavirus. PLoS Pathog. 2013, 9, e1003688. [CrossRef] [PubMed] 
37. Neu, U.; Maginnis, M.S.; Palma, A.S.; Ströh, L.J.; Nelson, C.D.S.; Feizi, T.; Atwood, W.J.; Stehle, T. Structure-function analysis of the human JC polyomavirus establishes the LSTc pentasaccharide as a functional receptor motif. Cell Host Microbe 2010, 8, 309-319. [CrossRef]

38. Stroh, L.J.; Maginnis, M.S.; Blaum, B.S.; Nelson, C.D.; Neu, U.; Gee, G.V.; O’Hara, B.A.; Motamedi, N.; DiMaio, D.; Atwood, W.J.; et al. The greater affinity of JC polyomavirus capsid for alpha2,6-linked lactoseries tetrasaccharide $\mathrm{c}$ than for other sialylated glycans is a major determinant of infectivity. J. Virol. 2015, 89, 6364-6375. [CrossRef]

39. Elphick, G.F.; Querbes, W.; Jordan, J.A.; Gee, G.V.; Eash, S.; Manley, K.; Dugan, A.; Stanifer, M.; Bhatnagar, A.; Kroeze, W.K.; et al. The human polyomavirus, JCV, uses serotonin receptors to infect cells. Science 2004, 306, 1380-1383. [CrossRef] [PubMed]

40. Assetta, B.; Maginnis, M.S.; Gracia Ahufinger, I.; Haley, S.A.; Gee, G.V.; Nelson, C.D.; O’Hara, B.A.; Allen Ramdial, S.A.; Atwood, W.J. 5-HT2 receptors facilitate JC polyomavirus entry. J. Virol. 2013, 87, 13490-13498. [CrossRef] [PubMed]

41. Stroh, L.J.; Gee, G.V.; Blaum, B.S.; Dugan, A.S.; Feltkamp, M.C.; Atwood, W.J.; Stehle, T. Trichodysplasia spinulosa-associated polyomavirus uses a displaced binding site on VP1 to engage sialylated glycolipids. PLoS Pathog. 2015, 11, e1005112. [CrossRef] [PubMed]

42. Khan, Z.M.; Liu, Y.; Neu, U.; Gilbert, M.; Ehlers, B.; Feizi, T.; Stehle, T. Crystallographic and glycan microarray analysis of human polyomavirus 9 VP1 identifies N-Glycolyl neuraminic acid as a receptor candidate. J. Virol. 2014, 88, 6100-6111. [CrossRef] [PubMed]

43. Erickson, K.D.; Garcea, R.L.; Tsai, B. Ganglioside GT1b is a putative host cell receptor for the Merkel cell polyomavirus. J. Virol. 2009, 83, 10275-10279. [CrossRef] [PubMed]

44. Schowalter, R.M.; Pastrana, D.V.; Buck, C.B. Glycosaminoglycans and sialylated glycans sequentially facilitate Merkel cell polyomavirus infectious entry. PLoS Pathog. 2011, 7, e1002161. [CrossRef] [PubMed]

45. Ströh, L.J.; Neu, U.; Blaum, B.S.; Buch, M.H.C.; Garcea, R.L.; Stehle, T. Structure analysis of the major capsid proteins of human polyomaviruses 6 and 7 reveals an obstructed sialic acid binding site. J. Virol. 2014, 88, 10831-10839. [CrossRef] [PubMed]

46. Neu, U.; Wang, J.; Macejak, D.; Garcea, R.L.; Stehle, T. Structures of the major capsid proteins of the human Karolinska Institutet and Washington University polyomaviruses. J. Virol. 2011, 85, 7384-7392. [CrossRef] [PubMed]

47. Moriyama, T.; Marquez, J.P.; Wakatsuki, T.; Sorokin, A. Caveolar endocytosis is critical for BK virus infection of human renal proximal tubular epithelial cells. J. Virol. 2007, 81, 8552-8562. [CrossRef] [PubMed]

48. Zhao, L.; Marciano, A.T.; Rivet, C.R.; Imperiale, M.J. Caveolin- and clathrin-independent entry of BKPyV into primary human proximal tubule epithelial cells. Virology 2016, 492, 66-72. [CrossRef] [PubMed]

49. Meneguzzi, G.; Pignatti, P.F.; Barbanti-Brodano, G.; Milanesi, G. Minichromosome from BK virus as a template for transcription in vitro. Proc. Natl. Acad. Sci. USA 1978, 75, 1126-1130. [CrossRef] [PubMed]

50. Wollebo, H.S.; Woldemichaele, B.; Khalili, K.; Safak, M.; White, M.K. Epigenetic regulation of polyomavirus JC. Virol. J. 2013, 10, 264. [CrossRef] [PubMed]

51. Bialasiewicz, S.; Rockett, R.J.; Barraclough, K.A.; Leary, D.; Dudley, K.J.; Isbel, N.M.; Sloots, T.P. Detection of recently discovered human polyomaviruses in a longitudinal kidney transplant cohort. Am. J. Transplant. 2016, 16, 2734-2740. [CrossRef] [PubMed]

52. Fratini, M.; Di Bonito, P.; La Rosa, G. Oncogenic papillomavirus and polyomavirus in water environments: Is there a potential for waterborne transmission? Food Environ. Virol. 2014, 6, 1-12. [CrossRef] [PubMed]

53. La Rosa, G.; Della Libera, S.; Petricca, S.; Iaconelli, M.; Briancesco, R.; Paradiso, R.; Semproni, M.; Di Bonito, P.; Bonadonna, L. First detection of papillomaviruses and polyomaviruses in swimming pool waters: Unrecognized recreational water-related pathogens? J. Appl. Microbiol. 2015, 119, 1683-1691. [CrossRef] [PubMed]

54. Monaco, M.C.; Major, E.O. Immune system involvement in the pathogenesis of JC Virus induced PML: What is learned from studies of patients with underlying diseases and therapies as risk factors. Front. Immunol. 2015, 6, 159. [CrossRef] [PubMed]

55. Bennett, S.M.; Broekema, N.M.; Imperiale, M.J. BK polyomavirus: Emerging pathogen. Microbes Infect. 2012, 14, 672-683. [CrossRef] [PubMed]

56. Babel, N.; Volk, H.D.; Reinke, P. BK polyomavirus infection and nephropathy: The virus-immune system interplay. Nat. Rev. Nephrol. 2011, 7, 399-406. [CrossRef] [PubMed] 
57. White, M.K.; Gordon, J.; Khalili, K. The rapidly expanding family of human polyomaviruses: Recent developments in understanding their life cycle and role in human pathology. PLoS Pathog. 2013, 9, e1003206. [CrossRef] [PubMed]

58. Ferenczy, M.W.; Marshall, L.J.; Nelson, C.D.; Atwood, W.J.; Nath, A.; Khalili, K.; Major, E.O. Molecular biology, epidemiology, and pathogenesis of progressive multifocal leukoencephalopathy, the JC virus-induced demyelinating disease of the human brain. Clin. Microbiol. Rev. 2012, 25, 471-506. [CrossRef] [PubMed]

59. Miskin, D.P.; Koralnik, I.J. Novel syndromes associated with JC virus infection of neurons and meningeal cells: No longer a gray area. Curr. Opin. Neurol. 2015, 28, 288-294. [CrossRef] [PubMed]

60. Kazem, S.; van der Meijden, E.; Feltkamp, M.C. The trichodysplasia spinulosa-associated polyomavirus: Virological background and clinical implications. Apmis 2013, 121, 770-782. [CrossRef] [PubMed]

61. Matthews, M.R.; Wang, R.C.; Reddick, R.L.; Saldivar, V.A.; Browning, J.C. Viral-associated trichodysplasia spinulosa: A case with electron microscopic and molecular detection of the trichodysplasia spinulosa-associated human polyomavirus. J. Cutan. Pathol. 2011, 38, 420-431. [CrossRef] [PubMed]

62. Chang, Y.; Moore, P.S. Merkel cell carcinoma: A virus-induced human cancer. Annu. Rev. Pathol. 2012, 7, 123-144. [CrossRef] [PubMed]

63. Liu, W.; Yang, R.; Payne, A.S.; Schowalter, R.M.; Spurgeon, M.E.; Lambert, P.F.; Xu, X.; Buck, C.B.; You, J. Identifying the target cells and mechanisms of merkel cell polyomavirus infection. Cell Host Microbe 2016, 19, 775-787. [CrossRef] [PubMed]

64. Ho, J.; Jedrych, J.J.; Feng, H.; Natalie, A.A.; Grandinetti, L.; Mirvish, E.; Crespo, M.M.; Yadav, D.; Fasanella, K.E.; Proksell, S.; et al. Human polyomavirus 7-associated pruritic rash and viremia in transplant recipients. J. Infect. Dis. 2015, 211, 1560-1565. [CrossRef] [PubMed]

65. Rennspiess, D.; Pujari, S.; Keijzers, M.; Abdul-Hamid, M.A.; Hochstenbag, M.; Dingemans, A.M.; Kurz, A.K.; Speel, E.J.; Haugg, A.; Pastrana, D.V.; et al. Detection of human polyomavirus 7 in human thymic epithelial tumors. J. Thorac. Oncol. 2015, 10, 360-366. [CrossRef] [PubMed]

66. Nelson, C.D.; Derdowski, A.; Maginnis, M.S.; O’Hara, B.A.; Atwood, W.J. The VP1 subunit of JC polyomavirus recapitulates early events in viral trafficking and is a novel tool to study polyomavirus entry. Virology 2012, 428, 30-40. [CrossRef] [PubMed]

67. Teunissen, E.A.; de Raad, M.; Mastrobattista, E. Production and biomedical applications of virus-like particles derived from polyomaviruses. J. Control. Release 2013, 172, 305-321. [CrossRef] [PubMed]

68. Li, T.-C.; Iwasaki, K.; Katano, H.; Kataoka, M.; Nagata, N.; Kobayashi, K.; Mizutani, T.; Takeda, N.; Wakita, T.; Suzuki, T. Characterization of self-assembled virus-like particles of merkel cell polyomavirus. PLoS ONE 2015, 10, e0115646. [CrossRef] [PubMed]

69. Norkiene, M.; Stonyte, J.; Ziogiene, D.; Mazeike, E.; Sasnauskas, K.; Gedvilaite, A. Production of recombinant VP1-derived virus-like particles from novel human polyomaviruses in yeast. BMC Biotechnol. 2015, 15, 68. [CrossRef] [PubMed]

70. Hale, A.D.; Bartkeviciute, D.; Dargeviciute, A.; Jin, L.; Knowles, W.; Staniulis, J.; Brown, D.W.; Sasnauskas, K. Expression and antigenic characterization of the major capsid proteins of human polyomaviruses BK and JC in Saccharomyces cerevisiae. J. Virol. Methods 2002, 104, 93-98. [CrossRef]

71. Chang, D.; Fung, C.Y.; Ou, W.C.; Chao, P.C.; Li, S.Y.; Wang, M.; Huang, Y.L.; Tzeng, T.Y.; Tsai, R.T. Self-assembly of the JC virus major capsid protein, VP1, expressed in insect cells. J. Gen. Virol. 1997, 78, 1435-1439. [CrossRef] [PubMed]

72. Stolt, A.; Sasnauskas, K.; Koskela, P.; Lehtinen, M.; Dillner, J. Seroepidemiology of the human polyomaviruses. J. Gen. Virol. 2003, 84, 1499-1504. [CrossRef] [PubMed]

73. Lundstig, A.; Dillner, J. Serological diagnosis of human polyomavirus infection. Adv. Exp. Med. Biol. 2006, 577, 96-101. [PubMed]

74. Viscidi, R.P.; Rollison, D.E.; Sondak, V.K.; Silver, B.; Messina, J.L.; Giuliano, A.R.; Fulp, W.; Ajidahun, A.; Rivanera, D. Age-specific seroprevalence of merkel cell polyomavirus, BK virus, and JC virus. Clin. Vaccine Immunol. 2011, 18, 1737-1743. [CrossRef] [PubMed]

75. Sroller, V.; Hamsikova, E.; Ludvikova, V.; Musil, J.; Nemeckova, S.; Salakova, M. Seroprevalence rates of HPyV6, HPyV7, TSPyV, HPyV9, MWPyV and KIPyV polyomaviruses among the healthy blood donors. J. Med. Virol. 2016, 88, 1254-1261. [CrossRef] [PubMed] 
76. Lee, P.; Plavina, T.; Castro, A.; Berman, M.; Jaiswal, D.; Rivas, S.; Schlain, B.; Subramanyam, M. A second-generation ELISA (STRATIFY JCV DxSelect) for detection of JC virus antibodies in human serum and plasma to support progressive multifocal leukoencephalopathy risk stratification. J. Clin. Virol. 2013, 57, 141-146. [CrossRef] [PubMed]

77. Plavina, T.; Subramanyam, M.; Bloomgren, G.; Richman, S.; Pace, A.; Lee, S.; Schlain, B.; Campagnolo, D.; Belachew, S.; Ticho, B. Anti-JC virus antibody levels in serum or plasma further define risk of natalizumab-associated progressive multifocal leukoencephalopathy. Ann. Neurol. 2014, 76, 802-812. [CrossRef] [PubMed]

78. Samimi, M.; Molet, L.; Fleury, M.; Laude, H.; Carlotti, A.; Gardair, C.; Baudin, M.; Gouguet, L.; Maubec, E.; Avenel-Audran, M.; et al. Prognostic value of antibodies to Merkel cell polyomavirus T antigens and VP1 protein in patients with Merkel cell carcinoma. Br. J. Dermatol. 2016, 174, 813-822. [CrossRef] [PubMed]

79. Gee, G.V.; O'Hara, B.A.; Derdowski, A.; Atwood, W.J. Pseudovirus mimics cell entry and trafficking of the human polyomavirus JCPyV. Virus Res. 2013, 178, 281-286. [CrossRef] [PubMed]

80. Schowalter, R.M.; Reinhold, W.C.; Buck, C.B. Entry tropism of BK and Merkel cell polyomaviruses in cell culture. PLoS ONE 2012, 7, e42181. [CrossRef] [PubMed]

81. O'Hara, B.A.; Rupasinghe, C.; Yatawara, A.; Gaidos, G.; Mierke, D.F.; Atwood, W.J. Gallic acid-based small-molecule inhibitors of JC and BK polyomaviral infection. Virus Res. 2014, 189, 280-285. [CrossRef]

82. Yatawara, A.; Gaidos, G.; Rupasinghe, C.N.; O’Hara, B.A.; Pellegrini, M.; Atwood, W.J.; Mierke, D.F. Small-molecule inhibitors of JC polyomavirus infection. J. Pept. Sci. 2015, 21, 236-242. [CrossRef] [PubMed]

83. Pastrana, D.V.; Brennan, D.C.; Cuburu, N.; Storch, G.A.; Viscidi, R.P.; Randhawa, P.S.; Buck, C.B. Neutralization serotyping of BK polyomavirus infection in kidney transplant recipients. PLoS Pathog. 2012, 8, e1002650. [CrossRef] [PubMed]

84. Pastrana, D.V.; Ray, U.; Magaldi, T.G.; Schowalter, R.M.; Çuburu, N.; Buck, C.B. BK polyomavirus genotypes represent distinct serotypes with distinct entry tropism. J. Virol. 2013, 87, 10105-10113. [CrossRef] [PubMed]

85. Randhawa, P.; Pastrana, D.V.; Zeng, G.; Huang, Y.; Shapiro, R.; Sood, P.; Puttarajappa, C.; Berger, M.; Hariharan, S.; Buck, C.B. Commercially available immunoglobulins contain virus neutralizing antibodies against all major genotypes of polyomavirus BK. Am. J. Transplant. 2015, 15, 1014-1020. [CrossRef] [PubMed]

86. Ray, U.; Cinque, P.; Gerevini, S.; Longo, V.; Lazzarin, A.; Schippling, S.; Martin, R.; Buck, C.B.; Pastrana, D.V. JC polyomavirus mutants escape antibody-mediated neutralization. Sci. Transl. Med. 2015, 7, 306 ra151. [CrossRef] [PubMed]

87. Broekema, N.M.; Imperiale, M.J. Efficient propagation of archetype BK and JC polyomaviruses. Virology 2012, 422, 235-241. [CrossRef]

88. Buck, C.B.; Pastrana, D.V.; Lowy, D.R.; Schiller, J.T. Efficient intracellular assembly of papillomaviral vectors. J. Virol. 2004, 78, 751-757. [CrossRef] [PubMed]

89. Li, R.; Sharma, B.N.; Linder, S.; Gutteberg, T.J.; Hirsch, H.H.; Rinaldo, C.H. Characteristics of polyomavirus BK (BKPyV) infection in primary human urothelial cells. Virology 2013, 440, 41-50. [CrossRef] [PubMed]

90. Justice, J.L.; Verhalen, B.; Kumar, R.; Lefkowitz, E.J.; Imperiale, M.J.; Jiang, M. Quantitative proteomic analysis of enriched nuclear fractions from BK polyomavirus-infected primary renal proximal tubule epithelial cells. J. Proteome Res. 2015, 14, 4413-4424. [CrossRef] [PubMed]

91. Verhalen, B.; Justice, J.L.; Imperiale, M.J.; Jiang, M. Viral DNA replication-dependent DNA damage response activation during BK polyomavirus infection. J. Virol. 2015, 89, 5032-5039. [CrossRef] [PubMed]

92. Jiang, M.; Zhao, L.; Gamez, M.; Imperiale, M.J. Roles of ATM and ATR-mediated DNA damage responses during lytic BK polyomavirus infection. PLoS Pathog. 2012, 8, e1002898. [CrossRef] [PubMed]

93. Jeffers-Francis, L.K.; Burger-Calderon, R.; Webster-Cyriaque, J. Effect of Leflunomide, Cidofovir and Ciprofloxacin on replication of BKPyV in a salivary gland in vitro culture system. Antiviral Res. 2015, 118, 46-55. [CrossRef] [PubMed]

94. Burger-Calderon, R.; Madden, V.; Hallett, R.A.; Gingerich, A.D.; Nickeleit, V.; Webster-Cyriaque, J. Replication of oral BK virus in human salivary gland cells. J. Virol. 2014, 88, 559-573. [CrossRef] [PubMed]

95. Alsanie, W.F.; Niclis, J.C.; Petratos, S. Human embryonic stem cell-derived oligodendrocytes: Protocols and perspectives. Stem Cells Dev. 2013, 22, 2459-2476. [CrossRef] [PubMed]

96. Schaumburg, C.; O’Hara, B.A.; Lane, T.E.; Atwood, W.J. Human embryonic stem cell-derived oligodendrocyte progenitor cells express the serotonin receptor and are susceptible to JC virus infection. J. Virol. 2008, 82, 8896-8899. [CrossRef] [PubMed] 
97. Major, E.O.; Miller, A.E.; Mourrain, P.; Traub, R.G.; de Widt, E.; Sever, J. Establishment of a line of human fetal glial cells that supports JC virus multiplication. Proc. Natl. Acad. Sci. USA 1985, 82, 1257-1261. [CrossRef] [PubMed]

98. Henriksen, S.; Tylden, G.D.; Dumoulin, A.; Sharma, B.N.; Hirsch, H.H.; Rinaldo, C.H. The human fetal glial cell line SVG p12 contains infectious BK polyomavirus. J. Virol. 2014, 88, 7556-7568. [CrossRef] [PubMed]

99. Brickelmaier, M.; Lugovskoy, A.; Kartikeyan, R.; Reviriego-Mendoza, M.M.; Allaire, N.; Simon, K.; Frisque, R.J.; Gorelik, L. Identification and characterization of mefloquine efficacy against JC virus in vitro. Antimicrob. Agents Chemother. 2009, 53, 1840-1849. [CrossRef] [PubMed]

100. Dang, X.; Chalkias, S.; Koralnik, I.J. JC virus-iLOV fluorescent strains enable the detection of early and late viral protein expression. J. Virol. Methods 2015, 223, 25-29. [CrossRef] [PubMed]

101. Israel, M.A.; Chan, H.W.; Hourihan, S.L.; Rowe, W.P.; Martin, M.A. Biological activity of polyoma viral DNA in mice and hamsters. J. Virol. 1979, 29, 990-996. [PubMed]

102. Small, J.A.; Scangos, G.A.; Cork, L.; Jay, G.; Khoury, G. The early region of human papovavirus JC induces dysmyelination in transgenic mice. Cell 1986, 46, 13-18. [CrossRef]

103. Haas, S.; Haque, N.S.; Beggs, A.H.; Khalili, K.; Knobler, R.L.; Small, J. Expression of the myelin basic protein gene in transgenic mice expressing human neurotropic virus, JCV, early protein. Virology 1994, 202, 89-96. [CrossRef] [PubMed]

104. Trapp, B.D.; Small, J.A.; Pulley, M.; Khoury, G.; Scangos, G.A. Dysmyelination in transgenic mice containing JC virus early region. Ann. Neurol. 1988, 23, 38-48. [CrossRef] [PubMed]

105. Small, J.A.; Khoury, G.; Jay, G.; Howley, P.M.; Scangos, G.A. Early regions of JC virus and BK virus induce distinct and tissue-specific tumors in transgenic mice. Proc. Natl. Acad. Sci. USA 1986, 83, 8288-8292. [CrossRef] [PubMed]

106. Shollar, D.; Del Valle, L.; Khalili, K.; Otte, J.; Gordon, J. JCV T-antigen interacts with the neurofibromatosis type 2 gene product in a transgenic mouse model of malignant peripheral nerve sheath tumors. Oncogene 2004, 23, 5459-5467. [CrossRef] [PubMed]

107. Spurgeon, M.E.; Cheng, J.; Bronson, R.T.; Lambert, P.F.; DeCaprio, J.A. Tumorigenic activity of Merkel cell polyomavirus $\mathrm{T}$ antigens expressed in the stratified epithelium of mice. Cancer Res. 2015, 75, 1068-1079. [CrossRef] [PubMed]

108. Verhaegen, M.E.; Mangelberger, D.; Harms, P.W.; Vozheiko, T.D.; Weick, J.W.; Wilbert, D.M.; Saunders, T.L.; Ermilov, A.N.; Bichakjian, C.K.; Johnson, T.M.; et al. Merkel cell polyomavirus small T antigen is oncogenic in transgenic mice. J. Invest. Dermatol. 2015, 135, 1415-1424. [CrossRef] [PubMed]

109. Shuda, M.; Guastafierro, A.; Geng, X.; Shuda, Y.; Ostrowski, S.M.; Lukianov, S.; Jenkins, F.J.; Honda, K.; Maricich, S.M.; Moore, P.S.; et al. Merkel cell polyomavirus small T antigen induces cancer and embryonic Merkel cell proliferation in a transgenic mouse model. PLoS ONE 2015, 10, e0142329. [CrossRef]

110. Herter-Sprie, G.S.; Kung, A.L.; Wong, K.K. New cast for a new era: Preclinical cancer drug development revisited. J. Clin. Investig. 2013, 123, 3639-3645. [CrossRef] [PubMed]

111. Arora, R.; Shuda, M.; Guastafierro, A.; Feng, H.; Toptan, T.; Tolstov, Y.; Normolle, D.; Vollmer, L.L.; Vogt, A.; Domling, A.; et al. Survivin is a therapeutic target in Merkel cell carcinoma. Sci. Transl. Med. 2012, 4, 133ra156. [CrossRef] [PubMed]

112. Dresang, L.R.; Guastafierro, A.; Arora, R.; Normolle, D.; Chang, Y.; Moore, P.S. Response of Merkel cell polyomavirus-positive merkel cell carcinoma xenografts to a survivin inhibitor. PLoS ONE 2013, 8, e80543. [CrossRef] [PubMed]

113. Tan, C.S.; Broge, T.A., Jr.; Seung, E.; Vrbanac, V.; Viscidi, R.; Gordon, J.; Tager, A.M.; Koralnik, I.J. Detection of JC virus-specific immune responses in a novel humanized mouse model. PLoS ONE 2013, 8, e64313. [CrossRef] [PubMed]

114. Kondo, Y.; Windrem, M.S.; Zou, L.; Chandler-Militello, D.; Schanz, S.J.; Auvergne, R.M.; Betstadt, S.J.; Harrington, A.R.; Johnson, M.; Kazarov, A.; et al. Human glial chimeric mice reveal astrocytic dependence of JC virus infection. J. Clin. Investig. 2014, 124, 5323-5336. [CrossRef] [PubMed]

115. Reid, C.E.; Li, H.; Sur, G.; Carmillo, P.; Bushnell, S.; Tizard, R.; McAuliffe, M.; Tonkin, C.; Simon, K.; Goelz, S.; et al. Sequencing and analysis of JC virus DNA from natalizumab-treated PML patients. J. Infect. Dis. 2011, 204, 237-244. [CrossRef] [PubMed] 
116. Gorelik, L.; Reid, C.; Testa, M.; Brickelmaier, M.; Bossolasco, S.; Pazzi, A.; Bestetti, A.; Carmillo, P.; Wilson, E.; McAuliffe, M.; et al. Progressive multifocal leukoencephalopathy (PML) development is associated with mutations in JC virus capsid protein VP1 that change its receptor specificity. J. Infect. Dis. 2011, 204, 103-114. [CrossRef] [PubMed]

117. Schaffhausen, B.S.; Roberts, T.M. Lessons from polyoma middle T antigen on signaling and transformation: A DNA tumor virus contribution to the war on cancer. Virology 2009, 384, 304-316. [CrossRef] [PubMed]

118. van der Meijden, E.; Kazem, S.; Dargel, C.A.; van Vuren, N.; Hensbergen, P.J.; Feltkamp, M.C. Characterization of $\mathrm{T}$ antigens, including middle $\mathrm{T}$ and alternative $\mathrm{T}$, expressed by the human polyomavirus associated with trichodysplasia spinulosa. J. Virol. 2015, 89, 9427-9439. [CrossRef]

119. Kemball, C.C.; Lee, E.D.; Vezys, V.; Pearson, T.C.; Larsen, C.P.; Lukacher, A.E. Late priming and variability of epitope-specific CD8+ T cell responses during a persistent virus infection. J. Immunol. 2005, 174, 7950-7960. [CrossRef] [PubMed]

120. Lin, E.; Kemball, C.C.; Hadley, A.; Wilson, J.J.; Hofstetter, A.R.; Pack, C.D.; Lukacher, A.E. Heterogeneity among viral antigen-specific CD4+ T cells and their de novo recruitment during persistent polyomavirus infection. J. Immunol. 2010, 185, 1692-1700. [CrossRef] [PubMed]

121. Frost, E.L.; Lukacher, A.E. The importance of mouse models to define immunovirologic determinants of progressive multifocal leukoencephalopathy. Front. Immunol. 2014, 5, 646. [CrossRef] [PubMed]

122. Han Lee, E.D.; Kemball, C.C.; Wang, J.; Dong, Y.; Stapler, D.C.; Hamby, K.M.; Gangappa, S.; Newell, K.A.; Pearson, T.C.; Lukacher, A.E.; et al. A mouse model for polyomavirus-associated nephropathy of kidney transplants. Am. J. Transplant. 2006, 6, 913-922. [CrossRef] [PubMed]

123. Albrecht, J.A.; Dong, Y.; Wang, J.; Breeden, C.; Farris, A.B., 3rd; Lukacher, A.E.; Newell, K.A. Adaptive immunity rather than viral cytopathology mediates polyomavirus-associated nephropathy in mice. Am. J. Transplant. 2012, 12, 1419-1428. [CrossRef]

124. Horvath, C.J.; Simon, M.A.; Bergsagel, D.J.; Pauley, D.R.; King, N.W.; Garcea, R.L.; Ringler, D.J. Simian virus 40-induced disease in rhesus monkeys with simian acquired immunodeficiency syndrome. Am. J. Pathol. 1992, 140, 1431-1440. [PubMed]

125. Dang, X.; Wuthrich, C.; Axthelm, M.K.; Koralnik, I.J. Productive simian virus 40 infection of neurons in immunosuppressed Rhesus monkeys. J. Neuropathol. Exp. Neurol. 2008, 67, 784-792. [CrossRef] [PubMed]

126. Wuthrich, C.; Koralnik, I.J. Frequent infection of cortical neurons by JC virus in patients with progressive multifocal leukoencephalopathy. J. Neuropathol. Exp. Neurol. 2012, 71, 54-65. [CrossRef] [PubMed]

127. Kaliyaperumal, S.; Dang, X.; Wuethrich, C.; Knight, H.L.; Pearson, C.; MacKey, J.; Mansfield, K.G.; Koralnik, I.J.; Westmoreland, S.V. Frequent infection of neurons by SV40 virus in SIV-infected macaque monkeys with progressive multifocal leukoencephalopathy and meningoencephalitis. Am. J. Pathol. 2013, 183, 1910-1917. [CrossRef] [PubMed]

128. Das, D.; Wojno, K.; Imperiale, M.J. BK virus as a cofactor in the etiology of prostate cancer in its early stages. J. Virol. 2008, 82, 2705-2714. [CrossRef] [PubMed]

129. Papadimitriou, J.C.; Randhawa, P.; Rinaldo, C.H.; Drachenberg, C.B.; Alexiev, B.; Hirsch, H.H. BK polyomavirus infection and renourinary tumorigenesis. Am. J. Transplant. 2016, 16, 398-406. [CrossRef] [PubMed]

(c) 2016 by the authors; licensee MDPI, Basel, Switzerland. This article is an open access article distributed under the terms and conditions of the Creative Commons Attribution (CC-BY) license (http://creativecommons.org/licenses/by/4.0/). 